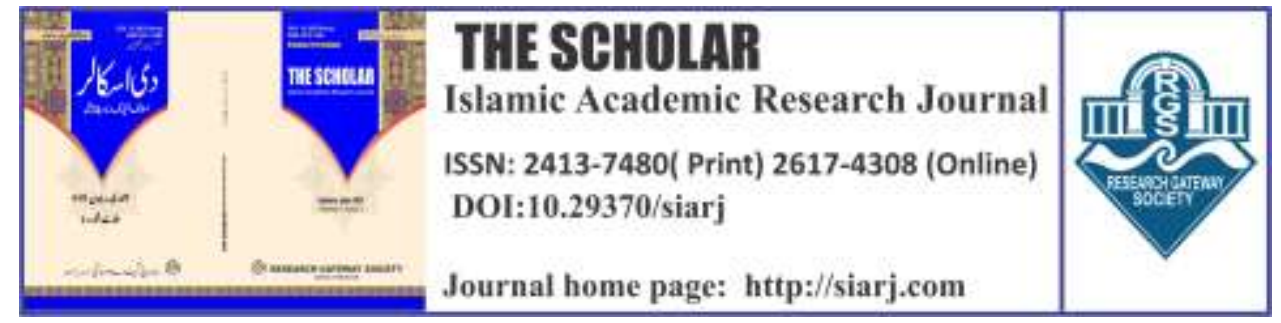

\title{
ESSENTIAL INGREDIENTS OF A 'CONFIDENT PERSONALITY’: AN ANALYTICAL STUDY OF THE ISLAMIC CONCEPTS OF TARBIYYAH
}

\author{
Muhammad Nabeel Musharraf \\ and New Zealand

\section{Email:admin@australianislamiclibrary.org \\ ORCID ID: \\ https://orcid.org/0000-0002-9987-5290}

Founder Australian Islamic Library, Member Islamic Circle of Australia

To cite this article:

Musharraf, Muhammad Nabeel. "ESSENTIAL INGREDIENTS OF A 'CONFIDENT PERSONALITY': AN ANALYTICAL STUDY OF THE ISLAMIC CONCEPTS OF TARBIYYAH." The Scholar-Islamic Academic Research Journal 7, no. 2 (December 29, 2021)

To link to this article: https://doi.org/10.29370/siarj/issue13ar6

\begin{tabular}{|c|c|}
\hline Journal & $\begin{array}{l}\text { The Scholar Islamic Academic Research Journal } \\
\text { Vol. 7, No. } 2 \text { ||July -December } 2021 \text { || P.101-126 }\end{array}$ \\
\hline Publisher & Research Gateway Society \\
\hline DOI: & 10.29370/siarj/issue13ar6 \\
\hline URL: & https://doi.org/10.29370/siari/issue13ar6 \\
\hline License: & Copyright c 2017 NC-SA 4.0 \\
\hline Journal homepage & www.siarj.com \\
\hline Published online: & $2021-12-29$ \\
\hline
\end{tabular}
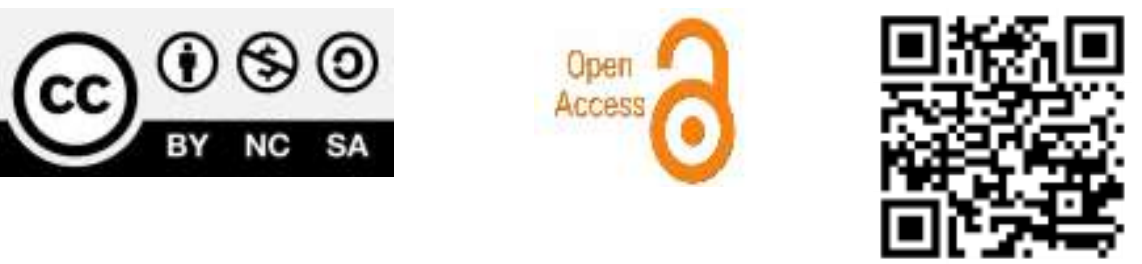
THE SCHOLAR (July-December 2021)

\title{
ESSENTIAL INGREDIENTS OF A 'CONFIDENT PERSONALITY': AN ANALYTICAL STUDY OF THE ISLAMIC CONCEPTS OF TARBIYYAH
}

\author{
Muhammad Nabeel Musharraf
}

\begin{abstract}
:
Being the true and final word of Allah swt, the Quran provides us guidance about all spheres of our life - individual as well as communal. The principles of reformation of society that it outlines begin with the individuals and then they expand to include families, communities, nations, and ultimately the whole of mankind. If the first building block the individual - is not solid and strong, it will result in the weakness of all the subsequent levels. Islam, therefore, puts a strong emphasis on the holistic personality development of individuals. It has provided detailed guidance about all the essential aspects and ingredients of a confident Muslim personality. The details of these ingredients are abundantly elaborated through the blessed words and noble actions of the best of the creations, Muhammad aلlughale which have been recorded in the books of ahadith. We need to make ourselves aware of these ingredients and utilize them to shape our beings. We are more in need to remain in the pursuit of self-improvement in today's times than ever before. This article
\end{abstract}


is an attempt to present an overview of these essential ingredients and explain their basis, challenges in their implementation, and the factors that help us employ them. May Allah swt make us realize our true potential and enable us to perform our responsibilities as Muslims and as the messengers of the Messenger of Allah aلlulualle in the most befitting manner.

KEYWORDS: Self-belief, self-worth, confidence, creativity, character

\section{INTRODUCTION:}

The greater goals of education and tarbiyyah in Islam revolve around three important aspects: confidence, creativity, and character ${ }^{1}$. If these three things are achieved, it means that the greater goals of parenting and tarbiyyah have been achieved. These three aspects mutually support each other and if one of them gets enhanced, it results in a positive impact on the others (and vice versa). Character enables us to follow what is the right thing even if it means we will have to go through a difficult path or a path that we do not find many people to follow. Creativity is the art of forming doors in closed walls; it is about finding the right means to get to where you want to be without compromising on the foundational principles. It is, however, to be understood that the pre-requisite to creativity and character, as explained by Salman Asif Siddiqui - a renowned educationalist from

${ }^{1}$ Salman Asif Siddiqui, 3 Greater Goals of Parenting and Education, 2021, https://www.youtube.com/watch?v=p_0PzuGXnRY. 
Pakistan, is confidence ${ }^{2}$. Creativity and character would not be able to stand firm if there is no solid foundation of confidence underneath them to support their integrity and growth. Confidence makes us ready for life's experiences. When we are confident, we can easily move forward with people and opportunities - not back away from them. Even if we fail, confidence and belief in ourselves help us get back on our feet and attempt again. Therefore, in the context of holistic personality development from the Islamic perspective, it is essential to understand the factors that nurture or destroy confidence and then shape our parenting, educational, and societal practices in alignment with those points. The present article points out some of the essential ingredients of confidence according to the Islamic framework of tarbiyyah.

\section{WHAT IS MEANT BY CONFIDENCE?}

There are some stark differences in the Islamic and Western conceptions of confidence. In the West, confidence is often linked to 'boldness' or is considered as its synonym ${ }^{3}$. The Christian missionaries and preachers have also borrowed this 'definition' of confidence and equated it to

\section{${ }^{2}$ Siddiqui.}

${ }^{3}$ Anna Goldstein, Be Bold: A Guide to Unbreakable Confidence (United States: Rock Point Publishers, 2021), https://www.boomerangbooks.com.au/be-bold-aguide-to-unbreakable-confidence-volume-17/annagoldstein/book_9781631067327.htm; JUDI JAMES, "Boost Your Confidence: Simple Tricks to Become More Bold," Daily Mail, 2011, https://www.dailymail.co.uk/home/you/article-1368793/Boost-confidenceSimple-tricks-bold.html; Cambridge University Press, Cambridge Advanced Learner's Dictionary (Cambridge University Press, 2005). 
boldness ${ }^{4}$. When we look at Western thought, we also notice that confidence is considered as something that is given to people from the outside. It is often tied to factors such as 'success' (in worldly terms), educational achievements, abilities to negotiate, and personal well-being, among other things ${ }^{5}$. One of the motivating factors for people to do things is that they find other people doing them. They want to do what they do and want to have what they have. If others have got a lot of wealth, they get inspired and work hard to be like them and have a lot of money. If they get these things, they think that they have become superior. However, if they are unable to get the same or if they lose what they achieved, their confidence shatters. This is what happens when confidence is tied to delusional anchors.

However, the Islamic perspective in this regard is very different. Islam tells the man that he is in the sight of the Most High and He remembers him when he remembers Him. He (swt) is always near him. He (swt) has sent him as His deputy on earth and he is here on a mission. If this deep internal realization and sense of purpose is achieved, the man will not be willing to give up his mission irrespective of the resistance and hardships faced by him. People's making fun of him and throwing of stones at him would not shatter him and he will continue with his mission. When one is in this pursuit, success is not determined by whether one reaches the

${ }^{4}$ Dale Kuiper, "Boldness" (Protestant Reformed Churches in America, 2008), http://www.prca.org/Word\%20a\%20Week/Word59.htm.

${ }^{5}$ Kelsey Evelyn Perkins, "The Integrated Model of Self-Confidence: Defining and Operationalizing Self-Confidence in Organizational Settings" (PhD Thesis, 2018). 
destination or not. If one is on the path, he is successful even if he dies on the path without reaching the destination. If one develops the confidence to pursue this greater goal, he does not get bothered with minor things irrespective of how much bigger some people perceive them to be. If we can awaken this type of confidence within us, it will be long-term confidence. Allama Iqbal puts this concept in the following verses:

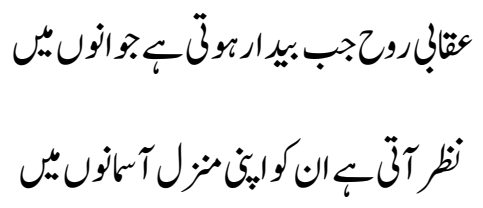

When the spirit of eagle awakens in the youth; they see their destination in the skies.

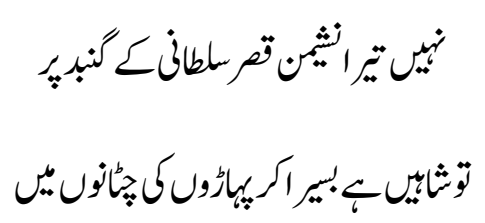

Your abode is not on the domes of the palaces of the kings! You are an eagle. Go and stay on the peaks of mountains! ${ }^{6}$

With this mindset, the person would not lose confidence if he does not get good grades, or is not able to find a good job, or is put with certain labels, and so on.

Another aspect in which the Islamic concept of confidence differs from its Western perception is the belief that the child is born on a pure nature -

${ }^{6}$ Allama Muhammad Iqbal, "Aik Nojawan ke Naam [To a young man]," in Baal e Jibril, 1935, https://www.rekhta.org/nazms/ek-nau-javaan-ke-naam-tire-sofehain-afrangii-tire-qaaliin-hain-iiraanii-allama-iqbal-nazms?lang=ur. 


\section{Essential Ingredients of a 'Confident Personality': An}

Analytical Study of the Islamic Concepts of Tarbiyyah

$\overline{\text { fitrah (Saheeh Bukhari 1292). It comes into this world with remarkable }}$ attributes and great confidence. A young child is not shy of asking what he needs or seeking attention and expressing himself in whatever ways are accessible to him. However, over a while, children develop certain fears and complexes based on their observation of the adults and gradually lose their confidence. In favorable conditions, their confidence grows. In unfavorable conditions, it dies. The concept of personality development in Islam is, therefore, about restoring the pure nature and confidence that the child comes into this world with. Its goal is to make people genuinely believe that they are important without being arrogant. This genuine belief should be based on the right reasons.

\section{INGREDIENTS OF CONFIDENCE:}

Confidence has many inter-related components. They are interlinked and interconnected with each other. In this article, we have discussed the following five aspects.

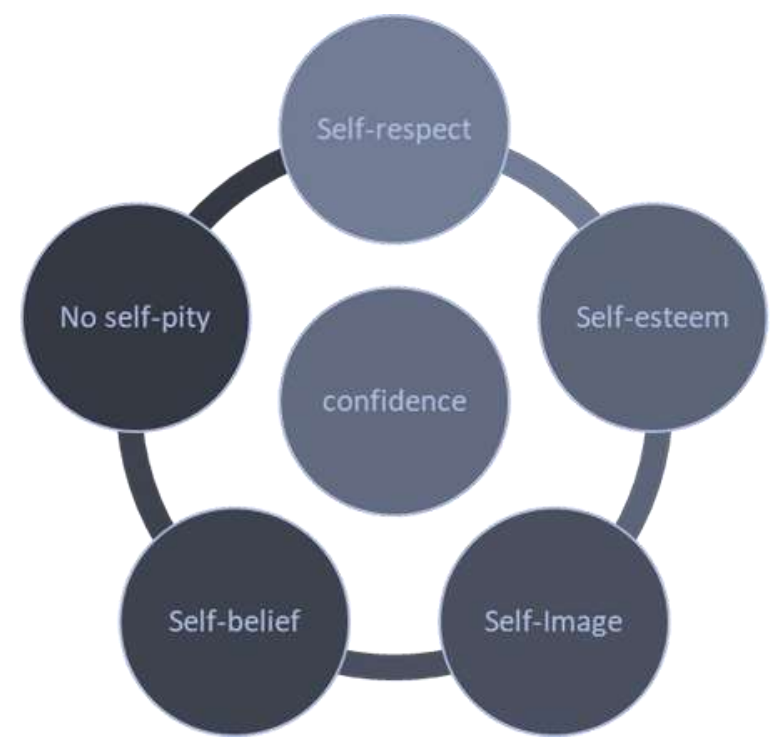

Figure 1: Factors that affect confidence 
Essential Ingredients of a 'Confident Personality': An Analytical Study of the Islamic Concepts of Tarbiyyah

\subsection{SELF-RESPECT:}

One of the most important factors that determine confidence is selfrespect. Disrespect crushes the confidence. That is why we see a strong emphasis in the Quran and sunnah on preserving the self-respect of others. Allah swt says:

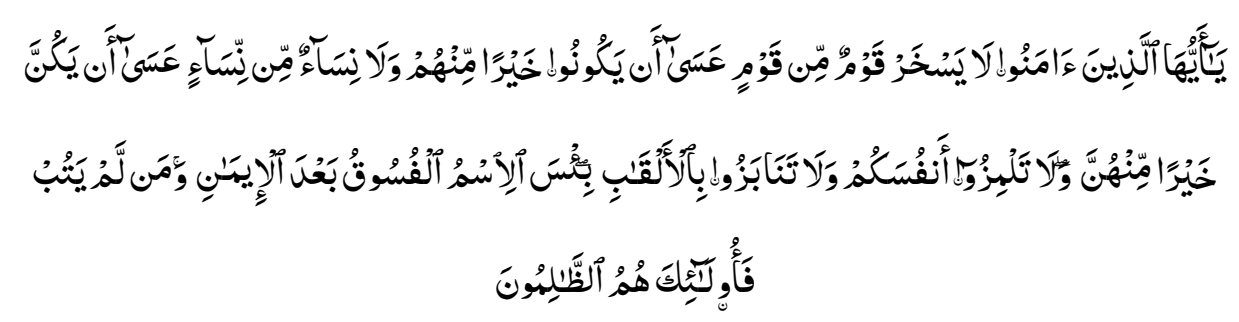

O believers! Let no men laugh at other men who may perhaps be better than themselves; and let no woman laugh at another woman, who may perhaps be better than herself. Do not defame through sarcastic remarks about one another, nor call one another by offensive nicknames. It is an evil thing to be called by a bad name after being a believer, and those who do not repent are the ones who are the wrongdoers.

(Surah Hujurat, Ayah 11)

The hadith below also highlights the importance of respecting other people:

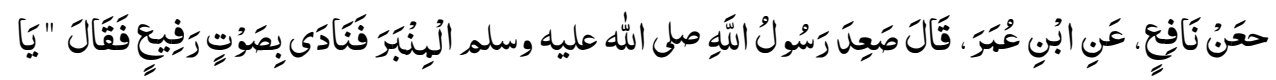

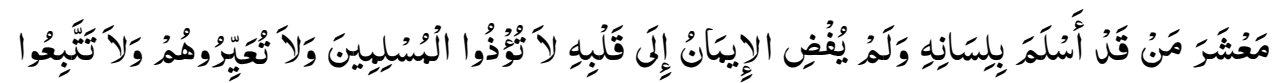

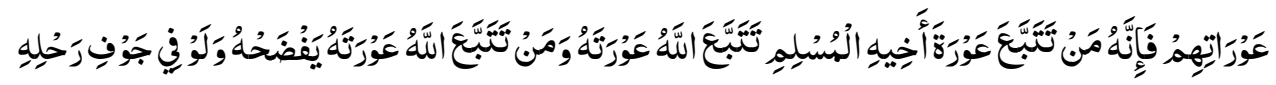

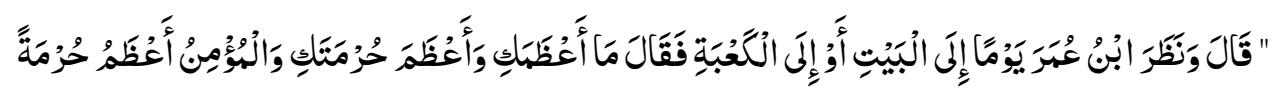

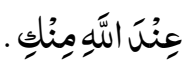

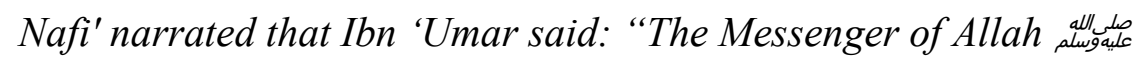


Essential Ingredients of a 'Confident Personality': An Analytical Study of the Islamic Concepts of Tarbiyyah

ascended the Minbar and called out with a raised voice: 'O you who accepted Islam with his tongue, while faith has not reached his heart! Do not harm the Muslims, nor revile them, nor spy on them to expose their secrets. For indeed whoever tries to expose his Muslims brother's secrets, Allah exposes his secrets wide open, even if he were in the depth of his house." He (Nafi') said: 'One day Ibn 'Umar looked at the House - orthe Ka'bah and said: 'What is it that is more honored than you, and whose honor is more sacred than yours! And the believer's honor is more sacred to Allah than yours. ",

(Jami at-Tirmidhi 2032)

Also consider the hadith below:

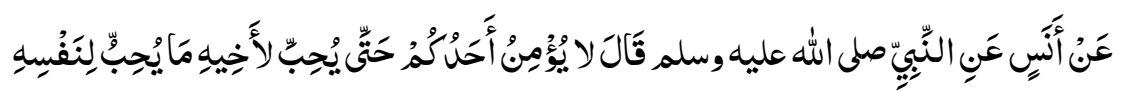

Anas ibn Malik reported: The Prophet, peace, and blessings be upon him, said, "None of you will have faith until he loves for his brother what he loves for himself."

(Saheeh Bukhari 13)

Many people misunderstand this hadith and think that it is only about things of physical nature. This is the problem of the current era in which we look at things only from the perspective and lens of materialism. The hadith above is not just related to materialistic things. It is generic in nature and has wider applications. It also means that we should ensure the same level of respect for others as what we seek for ourselves. It is also important to understand that this hadith is not just talking about the adults. It includes children too. They should be given their due respect too to keep their confidence intact. 


\subsection{SELF ESTEEM}

There are three factors that need to be understood in order to understand the concept of self-esteem.

\subsubsection{Identification of the ideal or the desired state}

Human consciousness can and is inclined to establish 'ideal' states for given situations and roles. If not in a pressured environment, one can easily explain what the ideal state would be in one's opinion and where is he standing in comparison to that ${ }^{7}$. An example of that can be seen in the year-end appraisals; many companies are increasingly asking employees to do self-assessment. If they are being 'honest', they can find what is the 'ideal state' of their role. This 'honestly', in Islamic terms, is called 'Ikhlas'. In short, the human brain is able to develop a feeling of what is ideal based on one's learning, exposures, life experiences, and beliefs. Where we fall short of the ideal, we get a feeling in our mind that we are not achieving the ideal outcomes. There is a caller in our hearts that tells us about this.

It needs to be understood that though we have all got the potential to develop the feeling of what the 'ideal' is, there is a possibility that we can formulate it incorrectly. Relying on acquired knowledge, and other human faculties alone cannot guide us to the truth in its entirety. We, therefore, need the light of divine guidance ${ }^{8}$ in order to correctly identify the goals

7 Salman Asif Siddiqui, What Is Self-Esteem? (Karachi: ERDC, 2019), https://www.youtube.com/watch?v=_uTJJf2ljUk.

${ }^{8}$ Muhammad 'Uthman Najati, Qur'an Wa-'ilm al-Nafs (Beirut: Dar al-Shuruq, 1982). 


\section{Essential Ingredients of a 'Confident Personality': An Analytical Study of the Islamic Concepts of Tarbiyyah}

and ideals that are worth striving for.

Identification of the right ideals is a matter of great significance. If you are unable to discover what the correct ideal is and if you bury yourself in the pursuit of false ideals and idols, you will forget your own self! You would be running after things that will make you get tired. You will forget the purpose, goals, and objectives of your own life. Incorrect ideals can turn your lives into misery.

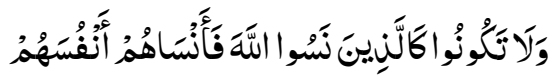

And be not like those who forgot Allah so He made them forget themselves.

(Sūratul Hashr, No.59, Ayat 19)

It is therefore very important to attach ourselves and our thinking with the correct ideology and thought patterns. Our beautiful religion has told us what these thought patterns should be and has given us a way of life that defines the 'ideal state' for us for all of our roles. It is the light of 'ilm' that would illuminate these ideals for us. It is extremely important to understand our mandatory roles and to exert an effort to achieve excellence in them. We have also been given the embodiment of 'the

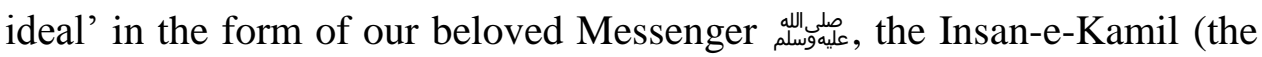
perfect human being in all aspects). We should ponder on his luminous life and seek guidance from it about what ideal really means.

\subsubsection{Identification of the current state}

One should keenly engage in the process of self-assessment and identification of what needs to be improved. Ikhlas is the factor that determines how much effort we will put into assessing where we are 
The Scholar Islamic Academic Research Journal

Vol. 7, No. 2 || July -December 2021 || P. 101-126

https://doi.org/10.29370/siarj/issue13ar6

standing ${ }^{9}$. The more ikhlas one has, the more critically he will look at himself and try to improve himself. Ikhlas enables us to have the ability to see the difference between where one is and where one wants to be. It enables Marifat Al-Nafs - to know one's self, strengths, weaknesses, opportunities for improvement, thinking patterns and their outcomes, feelings, and so on. Reflect to understand who you are.

The widespread problem of today's time, unfortunately, is that there is a famine in terms of deep pondering and reflection. We have become so excessively busy with the thick of thin that we find no time and inclination towards spending time with ourselves and understanding our realities ${ }^{10}$. Self-awareness and self-assessment are not a part of the daily lives of many of us anymore. Our focus is on the outside rather than the inside. We have more possessions and fewer good values. We are living in houses that are unable to become homes.

\subsubsection{The desire to move from the current state to the ideal state}

The motivation for moving from the current state to the ideal state is called self-esteem ${ }^{11}$. You would have higher self-esteem if you have a high desire for moving from where you are to where you are supposed to be. This higher desire would come through attachment with ilm. The ilm

\footnotetext{
${ }^{9}$ Siddiqui, What Is Self-Esteem?

${ }^{10}$ Salman Asif Siddiqui, Relationships \& the Meaning of Life (Karachi: ERDC, 2019), https://www.youtube.com/watch?v=KjvH81MnGTE.

${ }^{11}$ Siddiqui, What Is Self-Esteem?
} 
The Scholar Islamic Academic Research Journal

Vol. 7, No. 2 || July-December 2021 || P. 101-126

https://doi.org/10.29370/siarj/issue13ar6

would make you aware of the gap between the current and the desired ${ }^{12}$. It will give you a feeling of remorse about what you are missing and motivate you to strive. The greater the remorse, the greater will be the mujahidah that you will do.

If you are able to develop this high esteem, you will start having joy in the journey. Each step that takes you closer to your goal will give you pleasure and comfort even if that step was taken by stepping on the thorns. You will not be worried about proving yourself right but pursuing what is right. Maulana Ahmed Raza Khan points out about this pleasure in pain in the following words:

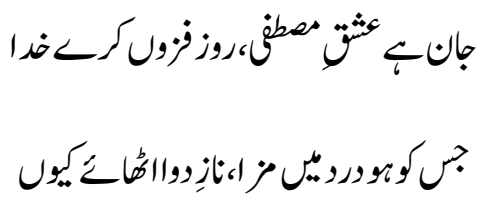

The love of the Prophet allingale is the real life. May Allah swt increase it every day. Why would the one who is enjoying the pain seek any cure for

$$
\begin{aligned}
& \text { it! }
\end{aligned}
$$

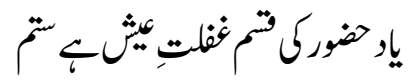

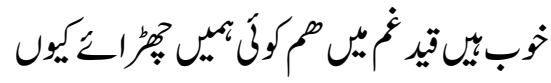

I take an oath by the feeling of longing for him! Being oblivious to one's comforts is sinful. We are in a lot of comforts while being the prisoners of

${ }_{12}$ Mokhtar Maghraoui, Tazkiyah Retreat: On Ilm (Madina Institute, 2016), https://www.youtube.com/watch?v=-T8WOmPyQ0k; Muhammad Nabeel Musharraf, Reviving the Hearts (Perth: Australian Islamic Library, 2019), https://www.researchgate.net/publication/330661726_Reviving_the_Hearts. 
The Scholar Islamic Academic Research Journal

Vol. 7, No. 2 || July -December 2021 || P. 101-126

https://doi.org/10.29370/siarj/issue13ar6

love and longing. Why would anyone think of making us free! ${ }^{13}$

\subsection{SELF-IMAGE:}

\subsubsection{The problem with low self-image:}

The suffering of our youth with poor self-image is one of the major challenges of the present times. It is one of the main reasons for people lacking self-confidence ${ }^{14}$. Being bombarded with visuals of men and women of certain characteristics and attributes, our young boys and girls develop an urge to look like them. Accordingly, they put a lot of effort into trying to look 'beautiful' according to the standards of beauty set by other people. These standards are set, most of the time, for commercial reasons and they keep on changing. When people are unable to attain the figure of the models they see on their screen or are not as tall or as fair as them and so on, they acquire an inferiority complex. According to research, $70 \%$ of young girls do not consider themselves to be 'beautiful' and avoid many important activities while suffering from this feeling ${ }^{15}$. Sometimes, people

\footnotetext{
${ }^{13}$ Maulana Ahmed Raza Khan Brelvi, "Phir ke Gali Gali Tabah [Moving street to street while being disheveled]," in Hadaiqe Bakhshish, vol. 1 (Pakistan: Maktabatul Madinah, 2018), 94, http://archive.org/details/MisbahiLibrary_Book_08.

${ }^{14}$ Prakash Sutradhar, "One of the Main Reasons for People Lacking SelfConfidence Is That They Have Poor Self-Image," Medium (blog), June 8, 2017, https://medium.com/@prakashee1/do-you-think-that-youre-not-beautiful-or-doyou-have-self-image-problem-76e50e 07c765.

${ }^{15}$ Syeda Saadia Ghaznavi, Nabi e Akram Bator Mahir e Nafsiat [The Prophet PBUH as an Expert of Psychology] (Zahid Basheer Printers, 1989), 53;
} 
The Scholar Islamic Academic Research Journal

Vol. 7, No. 2 || July -December 2021 || P. 101-126

https://doi.org/10.29370/siarj/issue13ar6

spend excessive amounts of money to change their appearances through makeup, as a short-term fix, and surgeries, as a long-term fix, which often results in de-shaping rather than any beautification. Why should we follow the false standards and remain discontent about ourselves?

The issue of poor self-image is not just related to dissatisfaction arising from one's physical appearance. They can engulf the whole personality. They can also result from being unable to do certain tasks and so on. Much of our youth are suffering from an inferiority complex because of this reason. Because of the feeling of low self-image and low self-worth, our brothers and sisters keep going down the spiral of stress and anxiety. People with low self-image do not consider themselves deserving of any rights. They often continue to live in abusive relationships and consider the fault to be their own ${ }^{16}$.

Just like other aspects of personality development, the solution to low selfimage starts from guarding one's thoughts. It is very rightly said that the body image starts in the mind, not in the mirror! ${ }^{17}$ We should carefully watch our thoughts as they become our words. Words become actions and actions become habits. Habits become character and character determines our destiny. It all starts with thoughts.

Sutradhar, "One of the Main Reasons for People Lacking Self-Confidence Is That They Have Poor Self-Image.”

16 "Self Esteem" (Better Health Channel, Department of Health, Victoria, 2016), https://www.betterhealth.vic.gov.au/health/healthyliving/self-esteem.

${ }^{17}$ The Canadian Mental Health Association, "Body Image, Self-Esteem, and Mental Health," 2015, https://www.heretohelp.bc.ca/infosheet/body-image-selfesteem-and-mental-health. 
The Scholar Islamic Academic Research Journal

Vol. 7, No. 2 || July-December 2021 || P. 101-126

https://doi.org/10.29370/siarj/issue13ar6

\subsubsection{How do people develop low self-worth and poor self- image?}

One can develop a negative self-image because of many factors. Some of them have been summarized below.

- The self-image of people is often damaged due to continuous criticism 18. When persistently told 'how bad they are', people start to believe that they actually are bad. We will discuss some of the ways to handle this in the next section.

- Often people develop positive or negative self-image based on how much and what type of worldly possessions they have ${ }^{19}$. It is to be remembered that this world is temporary and having or not having many possessions in this world does not matter much in the grand scheme of things. Allah swt says:

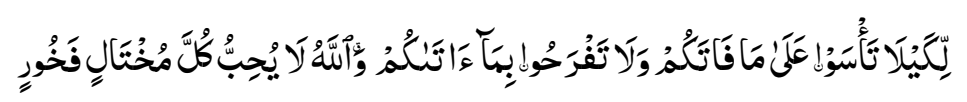

This is done so that you may not grieve for the things that you miss, or be overjoyed at what you gain; for Allah does not love any vainglorious boaster (Surah Hadeed, Ayah 23).

What matters is whether we will be successful in our real life, the one in the hereafter, or not. That is the life that will never end. As far as this world is considered, everything on it will be made flat as we are

\footnotetext{
18 "Self Esteem"; Sutradhar, "One of the Main Reasons for People Lacking SelfConfidence Is That They Have Poor Self-Image."

${ }^{19}$ Paul Sullivan, "Net Worth, Self-Worth and How We Look at Money," The New York Times, May 6, 2011, https://www.nytimes.com/2011/05/07/yourmoney/07wealth.html.
} 
The Scholar Islamic Academic Research Journal

Vol. 7, No. 2 || July -December 2021 || P. 101-126

https://doi.org/10.29370/siarj/issue13ar6

told in beginning ayat of Surah Al-Kahf. All the houses, cars, money, jewelry, branded clothing, and everything else on the surface of the earth will vanish. We should therefore aim for success in the neverending life. We should not feel important because of possessions, products, and status in this world. Their absence should not make us feel less important. Our aim and destination are elsewhere.

- Sometimes people feel good when they are praised, and they feel bad about themselves when they are not praised ${ }^{20}$. Our self-worth should not be based on external factors like praise. Worldly status, one's post or position, power, the suburb in which you live and the wealth of people living there, your lineage, race, and ethnicity - they are all incorrect reasons to feel good or bad about yourself! The correct criteria are what we have defined below.

\subsubsection{Where does positive self-image come from?}

When we start to think low about ourselves, we should remind ourselves of the following.

1) Allah swt has created us in a beautiful form. He swt says:

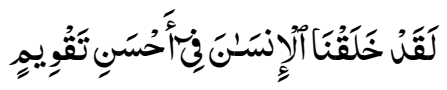

We have indeed created man in the best stature.

(Surah Teen, Ayah 4)

Similarly, Allah swt says:

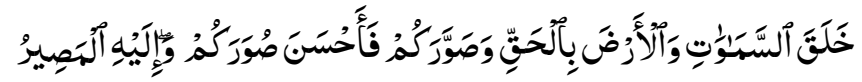

\footnotetext{
${ }^{20}$ Alfie Kohn, Punished by Rewards: The Trouble with Gold Stars, Incentive Plans, A's, Praise, and Other Bribes (Houghton Mifflin Company, 1999).
} 
The Scholar Islamic Academic Research Journal

Vol. 7, No. 2 || July -December 2021 || P. 101-126

https://doi.org/10.29370/siarj/issue13ar6

He created the heavens and the earth for a purpose. He shaped you, perfecting your form. And to Him is the final return.

(Surah Taghabun, Ayah 3)

This form does not just include our physical appearance but also the very many and diverse faculties that Allah swt has blessed us with, as we understand from the explanation of this ayah by Dr. Israr Ahmed ${ }^{21}$. Everyone is beautiful in someone's eye. Everyone is given one or more of the multiple intelligences ${ }^{22}$. If we are not as good at something as compared to others, we will definitely have something else that is much better than others ${ }^{23}$. We need to identify that unique talent and intelligence of ours and then put it to its best use.

2) We are worthy because we are linked to The One Most High. The one who is associated with Him cannot be low. You have such a relation with Him that when you remember Him, He remembers you. If you do so alone, $\mathrm{He}$ does that alone. If you do it in a gathering, He does it in a gathering better than yours (as we learn from the hadith no. 5138 from Musnad Al-Bazzar.) You should cherish this wonderful relationship with The One Who says (interpreted meaning): "Whoever draws close to Me by the length of a hand, I will draw close to him by the length of an arm. Whoever draws close to Me the by the length of an arm, I will draw close

\footnotetext{
${ }^{21}$ Tafseer Surah At-Teen (Lahore: Quran Academy, 1995), https://www.youtube.com/watch?v=SBMZxnAr8_0.

${ }^{22}$ Howard Gardner, Frames Of Mind (Basic Books Inc. Publishers, 1983).

${ }^{23}$ Ghaznavi, Nabi e Akram Bator Mahir e Nafsiat [The Prophet PBUH as an Expert of Psychology].
} 
The Scholar Islamic Academic Research Journal

Vol. 7, No. 2 || July -December 2021 || P. 101-126

https://doi.org/10.29370/siarj/issue13ar6

to him by the length of a fathom. Whoever comes to Me walking, I will come to him running. Whoever meets $\mathrm{Me}$ with enough sins to fill the earth, not associating any partners with Me, I will meet him with as much forgiveness" (Saheeh Muslim 2687). This is the type of intimate relationship He has with His people! How can then you consider yourself to be low. The only one who would be low would be the one who is not connected to the Most-High.

In this regard, Shaykh Yasser Fazaga ${ }^{24}$ presented the example of Usama Ibn Zaid. Once Hakeem Ibn Hazam gifted the gown of Caesar to the

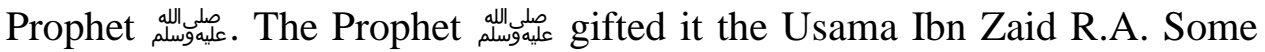
people did not see the beauty in Usama from the physical perspective. When Hakeem saw him wearing that gown, he said to him, 'O Usama, you are wearing the gown of the king of Yemen!'. Rather than feeling bad about not meeting certain 'standards of beauty' from the worldly perspective, Usama R.A. showed a very high self-image. He replied to Hakeem: I am better than him! My father was better than his! And my mother was better than his! Because we are the people of La Ilaha Ila Allah! This is the real source of our self-worth and positive self-image for us as Muslims.

3) Allah swt has told us another criterion of how one can become superior to others.

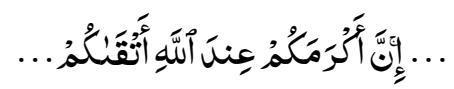

Surely the most noble of you in the sight of Allah is the most righteous

24 Self-Image Psychology (Peave TV, 2010),

https://www.youtube.com/watch?v=bJFmCG_-_34. 
The Scholar Islamic Academic Research Journal

Vol. 7, No. 2 || July-December 2021 || P. 101-126

https://doi.org/10.29370/siarj/issue13ar6

among you.

(Surah Hujurat, Ayah 13)

The person of taqwa is certainly better than others even though he would not have much wealth or beauty from the worldly perspective.

4) Another important aspect that promotes a positive self-image is the fact that Allah swt has chosen you to be his Khalifa on earth! He has chosen

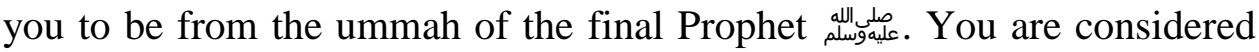
as worthy of being given the responsibility to be the flag-bearer of the

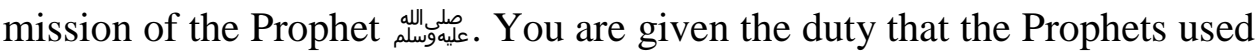
to do in the earlier times. Now consider this appointment of yours in the perspective of the ayah below:

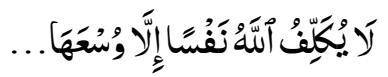

Allah does not burden any human being with more than he can bear.

(Surah Baqarah 286)

It means that when you are given the responsibility, you are given the potential to accomplish this too. How can a person with such huge potential feel low about himself?

5) Another important aspect that takes away our worries and feelings of low self-worth is Ishq - the utmost love for the Most High and His

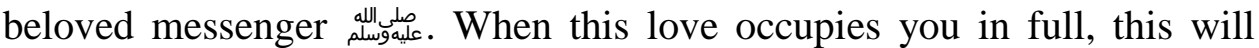
make you free of all worries about matters that don't really matter in the overall scheme of things. Allama Muhammad Iqbal beautifully put this point in the following verses:

$$
\begin{aligned}
& \text { ووعالمسكرنقبية بـنولك }
\end{aligned}
$$

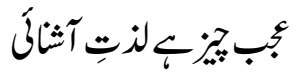


The Scholar Islamic Academic Research Journal

Vol. 7, No. 2 || July-December 2021 || P. 101-126

https://doi.org/10.29370/siarj/issue13ar6

(The taste of 'knowing' is a very strange thing; this makes one free of need

of everything)

\subsubsection{How should we deal with those who try to give us low self-worth by disrespecting us or humiliating us?}

- As a first step, you should be thankful to them that by disrespecting you, they saved you from being arrogant. It is to be kept in mind that if you are being criticized without having done the wrong, it is a great means for your self-improvement, as explained by Syed Ali Hajvery R.A. ${ }^{25}$

- We should love for others what we love for ourselves. If we wish to be lovingly told about any mistakes in our behaviors, we should do the same for others. We should guide them about the mistake in their behavior and request them to change it so that they can avoid the consequences of their deeds in the hereafter.

- If they don't refrain and continue to disrespect you, you can feel pity for them as they are accumulating sins for doing what they are doing, and meanwhile, you are getting the hasanat by remaining patient on this. Some scholars used to send gifts to such people that they took away their sins by disrespecting them ${ }^{26}$.

${ }^{25}$ Syed Ali Hajvey and Mian Tufail Muhammad, Kashaf-Ul-Mahjoob (Islamic Publications, Lahore, 2013), 91.

${ }^{26}$ Abi Laith Nasr As-Samarkandi, Tanbeeh Al-Ghafileen Bi Ahadith Syed AlAnbia Wa Al-Musaleen (Dar Al Kotob Al Ilmiyah, 2016), 90. 
The Scholar Islamic Academic Research Journal

Vol. 7, No. 2 || July -December 2021 || P. 101-126

https://doi.org/10.29370/siarj/issue13ar6

\subsection{SELF-BELIEF:}

\subsubsection{Realize what is in your hands}

Self-belief means that one should think that 'I can do it', and 'I am important' and still remain humble. Let us understand this concept with an example. If there is some rubbish on the road, people will consider the following options to be available to them. Some people will think that 'as it is already there now'; it is fine to add more rubbish to it; after all they are not the ones who started it. Others will think that whoever has done that has done a bad thing; they will decide, individually, not to add anything further to it. Some will go a step beyond this and decide among their people or group that none of them would add anything to it. And then there are those who go a level higher than this; they might decide to gather people and clean the road from that rubbish. Some people will take an even bigger mission and say that they will not only stop adding anything to this rubbish but also stop others from adding anything to it. The option that people choose will be determined by the level of self-belief and interest in the matter that they have. The people with lower self-belief will think that there is nothing in their hands and accordingly they will do nothing. An example of this type of attitude can be seen in what Bani Israel said to Musa A.S.:

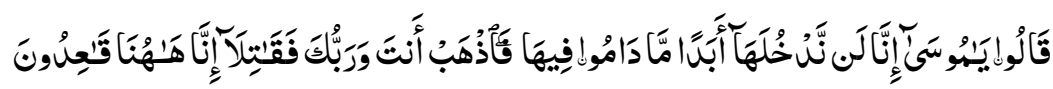

They replied, "O Musa! We will never enter it so long as they remain therein. Therefore, both you and your Rabb should go and fight, we will stay here."

(Surah Maida, Ayah 24)

What is mentioned about their statement in Bible shows a further 
The Scholar Islamic Academic Research Journal

Vol. 7, No. 2 || July -December 2021 || P. 101-126

https://doi.org/10.29370/siarj/issue13ar6

description of their lack of self-belief. They are reported to have said to Musa A.S. that the people Musa A.S. is asking them to fight with are very strong and they used to see themselves in front of them as grasshoppers (Numbers 13:33b). Contrary to this behavior, the people with higher selfbelief do not hesitate to stand up against the prevalent problems and evils and do whatever is in their hands. They have a genuine belief that they can do something about the situation. Their mission will accordingly be that of Amr Bil Maroof wa Nahi An Al-Munkir. They tell their Prophet aلd aلم they will fight till the last drop of blood remains in their body and if he would ask them to take their horses into the ocean (while chasing the enemy), they will have no second thoughts in doing so. It is this self-belief that gives confidence to the Prophet eلd who who had tied stones to his belly while digging the trench to proclaim and name the countries and lands his people would succeed - those people who didn't even have the food to eat at the time! But he had the belief and conviction that those superpowers will fall in the feet of his blessed and noble companions. This is the selfbelief that a drop of which will be sufficient for the ummah to reshape our lives.

\subsubsection{Deconstructing negative and limiting thoughts}

Once one realizes the importance of self-belief, the next important step is to de-construct the thoughts that result in low self-belief. That would become possible if one carefully guards one's thoughts and thinks them through in seclusion. There are some mental blocks that need to be identified. Some of the mental blocks are as follows. 'I can't do it because..': 'I was not able to do it in the past and hence I can't do it now or in future', 'others have failed at this; how can I be successful', 'no one has tried that before; it is not worth it', 'people have told me that it doesn't 
The Scholar Islamic Academic Research Journal

Vol. 7, No. 2 || July-December 2021 || P. 101-126

https://doi.org/10.29370/siarj/issue13ar6

work', 'I am not capable enough', 'those who did it were great people of unmatched worthiness; how can I do what they did - I am far below them'; and so on. All people who do great things are often told that they are not worth anything and they can't achieve what they dream of. Not paying any consideration to such limiting thoughts from outside and inside them, they continue to pursue what they are convinced is the right thing to do and make this world a better place.

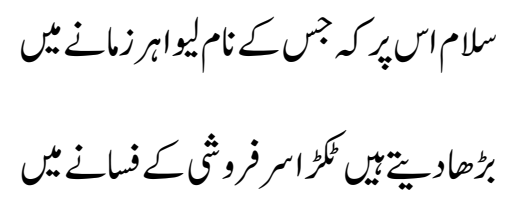

Peace be upon him whose lovers add another bit to the story of sacrifice in all eras.

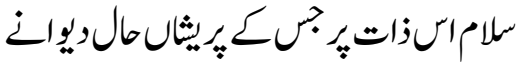

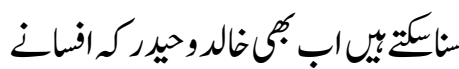

Peace be upon him whose disheveled followers can still show the same level of valor that we once used to hear about Khalid and Haider.

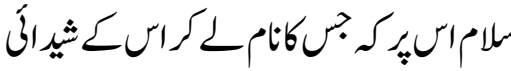

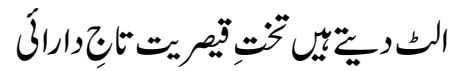

Peace be upon him with whose name the people that are mad in his love can put the thrones of Qaiser and the crown of Dara upside down! ${ }^{27}$

27 Mahir-ul-Qadri, Zahoor-e-Qudsi (Idara Adabiyat e Urdu, 1937), https://www.rekhta.org/ebooks/detail/zahoor-e-qudsi-mahirul-qadri-ebooks. 
The Scholar Islamic Academic Research Journal

Vol. 7, No. 2 || July -December 2021 || P. 101-126

https://doi.org/10.29370/siarj/issue13ar6

One should therefore start rediscovering the self-belief with the thought that 'I can do it'. Allah swt has blessed us with unimaginable potential. All we need to do is to sharpen it and then put it to use for the right causes. We should make dua to Allah swt to make us successful in our pursuit of goodness. Allah swt is capable of making extraordinary things happen from the apparently ordinary things. Even a meager mosquito is capable enough to kill the biggest of kings who has defeated many on the battleground. Small birds are capable enough to destroy the powerful armies of elephants. A young boy of seventeen years is capable enough to be the leader of the army that can defeat the greatest military powers. You are capable enough the do the next great thing for this ummah. I am capable enough to bring the change that our ummah needs. Our youth is capable enough to construct a brighter future for this ummah. Let us make the dua to Allah swt to make us the Imam of Al-Mutaqoon.

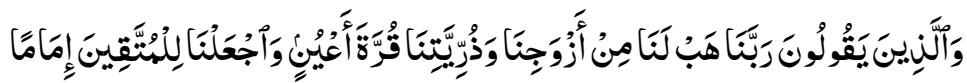

And those who say, "Our Lord! Grant to us from our spouses and our offspring comfort (to) our eyes and make us for the righteous a leader."

(Surah Furqan, Ayah 74)

\subsection{SELF-PITY}

A factor that shatters our confidence and self-belief is self-pity and victim mindset. It drains us of the mental faculties that we need to handle adversities in life and to pursue bigger goals ${ }^{28}$. This increases fears in

\footnotetext{
${ }^{28}$ Amy Morin, "Self-Pity Will Drain You Of The Mental Strength You Need To Get Through The Coronavirus Pandemic-Here's How To Avoid It," Forbes,
} 
The Scholar Islamic Academic Research Journal

Vol. 7, No. 2 || July-December 2021 || P. 101-126

https://doi.org/10.29370/siarj/issue13ar6

one's heart that people are out there to get him and hurt him. The person accordingly stops doing things which he otherwise is very much capable of.

To deal with this problem, one should train oneself to see good in what is happening. There is always a positive side to things. The challenges we face are a means of making us stronger.

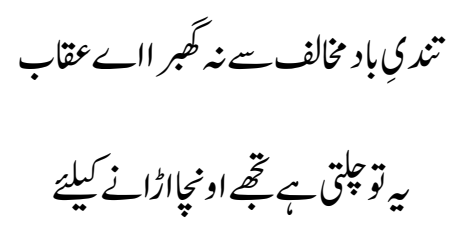

Do not worry about the strong headwinds, O eagle! They are blowing in such a manner only to make you fly higher! ${ }^{29}$

\section{CONCLUSION:}

In this article, we have explained the concept of confidence in the light of the Islamic system of tarbiyyah under five elements - self-respect, selfesteem, self-image, self-belief, and self-pity. These concepts are all interrelated and their relation to each other and 'confidence' is that of petals and the rose; or that of dominos - if one of them is impacted, the others are impacted too. The key to working on these and enhancing one's

2020, https://www.forbes.com/sites/amymorin/2020/04/08/self-pity-is-yourworst-enemy-in-getting-through-this-coronavirus-covid-19-pandemic-heres-howto-avoid-it/.

${ }^{29}$ Zulfiqar Ahsan and Syed Sadiq Hussain, Tanqeedi Ufaq (Rawalpindi: Naksh Gar, 2014), https://www.rekhta.org/ebooks/detail/tanqeedi-ufaq-zulfiqar-ahsanebooks. 
The Scholar Islamic Academic Research Journal

Vol. 7, No. 2 || July-December 2021 || P. 101-126

https://doi.org/10.29370/siarj/issue13ar6

self-confidence starts with managing the thought. If the thoughts are wellguarded and the mental blocks are avoided, nothing is stopping us from achieving a confident and thriving personality that would enable us to live a purposeful and meaningful life. 